\title{
Polish immigrants and their children in Canada and Sweden, employment status and income patterns
}

\author{
Ravi Pendakur ${ }^{1}$ and Pieter Bevelander ${ }^{2^{*}}$
}

\section{${ }^{*}$ Correspondence:}

pieter.bevelander@mau.se

${ }^{2}$ Malmö Institute for Studies

of Migration, Diversity,

and Welfare, Malmö

University, Malmö, Sweden

Full list of author information

is available at the end of the

article

\begin{abstract}
Using a combination of logit, and OLS regressions we ask if the labour force outcomes for Polish immigrants differ across two immigration policy regimes (Canada and Sweden). Specifically, we compare the employment and earnings prospects of Polish immigrants and their children in Canada and Sweden using data that is similar in quality and timing. We find that in general, Polish immigrants, while facing substantial penalties compared to native-born workers fare better in Canada than in Sweden in terms of employment and income. As expected, second generation Poles fare much better than their immigrant counterparts in terms of employment and earnings differentials and have similar outcomes to the native-born majority in both countries. Membership in the EU fundamentally changed migration flows from Poland. In light of this we also look at how post-2004 Polish migrants have fared in both Canada and Sweden.
\end{abstract}

Keywords: Immigrant economic integration, Polish minorities, Canada, Sweden

\section{Introduction}

The Polish diaspora is widespread, and prominent in Northern Europe, North America and Australia (see Drozdzewski, 2011; Forrest \& Kusek, 2016; Friberg, 2012a, 2012b; Garapich, 2008; Heydenkorn, 2009). In previous eras Polish migrants tended to work as agricultural labour however, that narrative has largely disappeared. Now, and in Europe in particular, the issue of Polish migration has been politicized as a robust source of skilled migration with the potential to substitute for local labour and complement labour demands, particularly at the low end of the market. Thus, a narrative of the "Polish plumber" which casts Poles as a source of skilled labour that is exploited, undercutting labour market regulations and wages has risen (see for example: Datta \& Brickell, 2009; Wagner, 2019 ${ }^{1}$; Leonard, 2014²; BBC, 2006³).

In this paper we compare labour market outcomes for Polish immigrants and their children in Canada and Sweden to understand how they fare in two countries with

\footnotetext{
1 Wagner, I. 2019. "Why freedom of movement is causing divisions-across Europe? The Guardian. January 162019. https://www.theguardian.com/commentisfree/2019/jan/16/freedom-movement-euroep-foreign-posted-workers-eu.

${ }^{2}$ Leonard, D. Exploding the myth of the Polish Plumber. Politico April 12 2014. https://www.politico.eu/article/explo ding-the-myth-of-polish-plumbers/.

${ }^{3}$ BBC. 2008. EU thumbs-up for 'Polish plumber'. http://news.bbc.co.uk/2/hi/uk_news/7735603.stm.
} author(s) and the source, provide a link to the Creative Commons licence, and indicate if changes were made. The images or other third party material in this article are included in the article's Creative Commons licence, unless indicated otherwise in a credit line to the material. If material is not included in the article's Creative Commons licence and your intended use is not permitted by statutory regulation or exceeds the permitted use, you will need to obtain permission directly from the copyright holder. To view a copy of this licence, visit http:// creativecommons.org/licenses/by/4.0/. 
broadly similar immigration rates and integration policies. Both Canada and Sweden have large immigrant populations and continue to welcome substantial numbers of new migrants annually (in excess of 300 thousand for Canada, and about 100 thousand annually in Sweden). In addition, both countries have substantial native-born minority populations. There are almost 37 thousand second generation Poles in Canada and almost 14 thousand in Sweden. This group should not be subject to many of the barriers faced by immigrants.

Comparing economic outcomes for Poles in Canada and Sweden is valuable for a number of reasons both because of intrinsic similarities and differences. Canada and Sweden both have long histories of accepting migrants for permanent residency who dominantly settle in the larger urban centres. With permanency comes access to almost all legal rights and citizenship acquisition requirements are relatively easy. However, where Canada has a substantial selection program for independent/labour migrants, combined with a large family class intake and a relatively small program for refugee intake, Sweden's labour intake relies dominantly on flows from within the EU, and a substantial asylum and family reunification program.

Under EU regulations, EU members can freely migrate to another EU state under the 'right of residence' law as long as they have sufficient means to support themselves. Thus, joining the EU offered Poles increased options in terms of settlement and decreased the cost of migration. However, EU regulation does not change labour market conditions in host European countries. Polish migrants would be expected to find work or pay their own way without drawing on the welfare state until they have permanent residency. For Canada, both labour market regulations and immigration regulations remained largely unchanged. There is a tacit understanding that permanent migrants are expected to contribute to the economy, but with permanency comes the option of state support.

With this in mind, we assess the labour outcomes for Polish immigrants and their children within the context of the immigration and labour market regimes that exist in Canada and Sweden using 2016 Canadian census and 2015 Swedish register data. Specifically, we look at the employment probabilities and earnings of Polish immigrants and their children in the two countries using data that is comparable in quality and timing. We compare employment probabilities, the log of income and the income rank (the place of individuals in the income distribution) of Polish immigrants and their children to Native born, non-Polish Canadians and Swedes. Thus, using Canada and Sweden as case studies, we ask-how do different migration contexts affect outcomes for Polish migrants and their children.

While most other studies use small samples or interview techniques, which make it difficult to generalize findings, we use Canadian Census and Swedish register data. These are large datasets which allow us to draw robust conclusions about labour force outcomes for both Polish immigrants, and their children. We note that this is one of the few studies to include an analysis of second-generation Poles in Canada and Sweden and the only one that looks at employment probabilities and earnings in Sweden.

We find that, after controlling for basic personal characteristics, Polish immigrants face smaller differentials in employment and income in Canada as compared to Sweden. Native-born Poles face no employment or earnings penalty in Canada, however, they do face fairly large differentials in Sweden. In order to evaluate earnings differentials more 
directly across countries we calculate the position of each person in the income distribution for Canada and Sweden by sex. This allows to more directly compare the rank of Poles versus other groups. Here we find that native-born Poles (both men and women) face virtually no difference or see a small bonus in the rank of earnings in Canada. In Sweden, Native-born Polish women show no difference in percent rank of earnings, and being a Native-born Polish man is correlated with a small decrease in the percentile rank of income.

\section{Theory and earlier studies}

There is a great deal of work on the place of human capital and the cost of migration on economic outcomes. Building on Becker's (1992) work, this perspective focuses on different individual characteristics, and argues that education and skills are important for explaining differences in the likelihood of obtaining employment as well as the relative difference in income between individuals. Applied to immigration, however, some educational qualifications and skills may not be perfectly transferable between countries. These skills could be labour-market information, destination-language proficiency and occupational licences, certifications or credentials, as well as more narrowly defined task-specific skills (Chiswick et al., 2005). The lower the international transferability of the skills, the wider the initial gap in native-immigrant employment and earnings. This initial gap, however, is expected to diminish with time in the country as immigrants acquire host country skills like language and other country specific skills.

Institutional factors like migration selection systems and integration policies can also affect integration of immigrants in the labour market. Canada uses a point system to select about a third of all immigrants based on the demand for skills which should increase the possibility that those admitted will "integrate" quickly into the labour market. ${ }^{4}$ Sweden does not use such a system but is part of the European Union which gives all EU citizens, including Polish citizens since 2004, mobility rights and the right to seek employment anywhere within the EU. While EU residents can freely enter Sweden and search for work, in practical terms, labour migration to Sweden is primarily demand driven. Economic immigrants usually have a job offer prior to entry however, with EU residents automatically getting permanent resident status, while non-EU immigrants would usually enter under limited term (renewable) contracts.

In general, regardless of policy regime, earlier studies on employment and earnings integration, conclude that immigrants have lower employment levels and earnings as compared to the native-born population (see Antecol et al., 2003; Borjas, 1994; Chiswick, 1978; OECD, 2007; Pendakur \& Pendakur, 2015).

Gorodzeisky and Semyonov (2017), maintain that there are two types of comparative studies. Most studies assess the labour market inclusion of immigrants (or different groups of immigrants) in a single host society. Far fewer studies take an international comparative perspective studying immigrant integration across countries. This study follows the second strategy, assessing the labour market inclusion of Polish immigrants and their children in two countries, Canada, and Sweden. This comparison allows us to

\footnotetext{
${ }^{4}$ In 2015 for example, over half of all permanent resident intake came as economic immigrants. However, only the primary applicant in a family is tested under the points system.
} 
understand how a specific group fares based on different policy and social circumstance. We add to this understanding by including an assessment of the native-born Polish population. In line with the economic assimilation model and in contrast to immigrants, the second generation is fostered and educated in the "host" society and should therefore not experience similar disadvantages as their parents in accessing and doing a career in the labour market.

One challenge to understanding the place of Poles in host countries is that research specific to Poles is relatively recent, and generally restricted to the post-EU expansion of 2004 (see for example: Burrell, 2010; Drozdzewski, 2011; Forrest \& Kusek, 2016; Kaczmarczyk \& Tyrowicz, 2015; Markowski and Kwapisz-Williams, 2013; Odé, 1996). Where the place of Polish immigrants is studied, it is often in the context of more global work that encompasses a large number of groups (see for example: Bevelander, 1999; Drinkwater et al., 2010; Kogan, 2010; Levrau et al., 2013). Work that looks at outcomes for the second generation is even rarer (Dahlstedt, 2015; Pendakur \& Pendakur, 1998, 2015).

In an Australia study Forrest and Kusek (2016), use Census data for the years 2006 and 2011, to trace the labour market and spatial integration of Polish immigrants as well as their children and grandchildren. They point to the importance of generational factors, concluding that there is a linear progression over generations and that third-generation individuals with Polish ancestry are indistinguishable from other Australians in terms of education attainment, home ownership and labour market participation. In Belgium a qualitative study on the Polish community in Antwerp show low unemployment levels for Polish immigrants compared to other immigrant groups (Levrau et al., 2013). Results for Germany by Kogan (2010) using 2005 microcensus data indicate that Polish immigrants have somewhat lower employment levels compared to native Germans. They conclude that the difference is mainly explained by human capital characteristics and not by an ethnic penalty. Conversely at all using register data for Germany from 1995 to 2006 conclude that the wage differentials between German and Polish immigrants were the largest of all East European groups. Miera (2008) looks more specifically at Polish entrepreneurs in Berlin using in-depth interviews. She points to the importance of transnational networks that allow Polish entrepreneurs to exploit cross-border differences in purchasing power of both goods and people to compete in the German market. In a similar study, Nowicka (2013), looks at transnationalism amongst seven Polish entrepreneurs in Munich. She uses Bourdieu's notions of capital to assess how different forms of capital (both social and fiscal) move across national boundaries, arguing that Polish migrants are able to exploit these resources and react to labour market demand (page 43).

Jon Friberg has taken several looks at Polish workers in Norway. Friberg (2012b) uses a combination of survey and register data to assess the probability of permanent moves by Polish migrant workers to Norway. He creates a model in which "decisions about length of stay, settlement and return are dependent upon the migrants' desires for the future and upon their opportunities to realise these desires (page 1603)." These desires can change over time based on the creation of changing work and social conditions. Similarly, Friberg et al (2014) looks at how labour market outcomes for Polish migration to Oslo, Copenhagen and Reykjavik, are shaped by the different labour markets. They conclude that all three regimes have problems both incorporating and protecting 
new migrant workers. Polish workers are particularly affected because they are often recruited for low skill, low wage occupations which lend themselves to exploitation. However, while cultural attributes can help in the short term, Friberg (2012a) argues that Norwegian employers are reluctant to offer permanent employment unless Polish workers assimilate to the "Norwegian work culture" (pp: 1914).

One of the countries that has had the largest inflow of Polish migrants since the enlargement of 2004 is the UK. Based on the Labour Force Survey for the years 20042007 of the UK, Drinkwater et al. (2010) show that the employment rate for Polish immigrants is 10 percent higher than the average employment level in the UK, about 9 percent higher than in other countries that joined the EU in 2004, and about 20 percent higher than other immigrant groups. Cieslik (2011) looked Polish workers in the UK within the context of job quality using a combination of 139 surveys and 60 in-depth interviews. She concludes that opportunities for advancement and employment conditions (such as child care) influence the decision to return to Poland, but that this is tempered by the opportunities that exist in Poland. Ciupijus (2011) looks at Polish labour migrants in the UK within the context of EU membership and post-national citizenship. He argues that, while EU membership offered greater opportunities for migration and lower working restrictions, work in the UK was characterized by downward occupational mobility. Garapich (2008) looks more specifically at the role of market forces on inclusion into both social and economic systems in the UK. He argues that the migration industry (defined as a set of for profit specialised social actors and commercial institutions) has usurped the place of traditional actors (such as the church or social service organizations) and that this is a positive move (page 736). Similar to Miera (2008) and Nowicka (2013), Knight et al (2014) look at the importance of social networks but in the context of Wales, a second level migration centre. They argue that social networks can act to both enable and disable labour market progression, with such networks being most useful in the initial stages of migration.

As noted above, a number of articles on employment integration include Poles as one of many groups studied. Bevelander (2000), for example, looks at employment levels for native Swedes and Polish immigrants (ages 20-64) for the census years 1960-1990 and shows that Polish males have an employment level of 81 percent in 1960 and only 70 percent in 1990. For native men the level is roughly 83 percent across the entire period. For female Polish immigrants the employment level in 1960 is 44 percent, rising to 64 percent in 1990. Native Swedish women in the same period show an employment rate of 36 percent in 1960, rising to 80 percent by1990. Bevelander argues that the declining employment success of (Polish) immigrants in the Swedish labour market is a result of broader structural changes which saw the economy move from a primarily industrial to a service economy with more flexible work organisations. This led to an up-shift in the demand for skilled qualifications which affected immigrants negatively. Rosholm, et al. (2006) come to a similar conclusion when comparing outcomes in Denmark and Sweden. Using a survey conducted by Statistics Sweden in the year 1993, Duvander (2001) tried to explain the unemployment risk for Finnish, Polish, Iranian and Chilean immigrants controlling for place of education (Sweden or in their home country), whether they speak and understand Swedish well, and lived with a Swedish partner. Their results indicated that the unemployment risk did not diminish substantially by including these 
factors and therefore the difference in unemployment risk between native and immigrants could be indicating discrimination.

Work on Polish minorities in Canada tends to be found in more global work on minorities in general. Pendakur and Pendakur (2015), for example use 2006 census data to look at earnings differentials for immigrants and Canadian-born minorities. They find that Polish immigrant men earn about 35 percent less than similarly qualified native-born majority males while Polish immigrant women earn about 39 percent less. Native-born Poles however, earn marginally more than native-born majority men and women.

Poland's entry into the European Union in 2004, changed the dynamic of migration for Poles. Where prior to 2004 migration was likely a permanent decision, regardless of the host country, it is now far more fluid within the EU, while the migration decision remains largely permanent for Canada. This has caused Polish immigration to slow in Canada and to increase within the EU. Over the last decade and a half, Polish migrants have increasingly found employment in Germany, the Netherlands, the UK, Norway and Sweden. Indeed in 2015, Poles were the second largest intra-EU migration group after Romania (Eurostat, 2020, see also Fihel and Kacmarczky 2004). ${ }^{5}$

Coyle (2007) provides an interesting take on Poland's entry into the EU by looking at the context of women's labour market equality and protection both within and outside Poland. She argues that prior to EU membership Polish women often obtained irregular work as cleaners or nannies that was precarious in nature. EU membership offers increased opportunities for work commensurate with skills outside Poland, but what is required is a legal framework for gender equality and rights in Poland, thereby allowing women to remain if they wish.

Overall past research points to large differentials in both employment probabilities and earnings for immigrants in general. In general, immigrants from Poland perform better than immigrants from outside Europe, and in the case of the UK and Germany can do the same or better than the native-born population (see Drinkwater et al., 2010; Kogan, 2010). As is to be expected, native-born Poles face much smaller differentials. Indeed, in Canada and Australia, native-born Polish men and women have basically the same probability of employment and similar wages after controlling for basic personal characteristics (see Pendakur \& Pendakur, 1998, 2015 and Forrest \& Kusek, 2016). Similarly, studies from the early and mid 2000s in Sweden find that Poles fare better than immigrants from outside Europe but still face substantial penalties in the labour market (Bevelander, 2000; Rosholm et al., 2006).

Clearly, migration context makes a difference in terms of self-selection of migrants and outcomes for Polish immigrants (see for example Ciupijus, 2011 and Drinkwater et al., 2010 Garapich, 2008, and Kogan, 2010). EU membership greatly reduced barriers to migration and allowed a larger number of Poles far greater choice in terms of host countries. This meant that Poles left Poland in greater numbers because those who would not have had the option to migrate prior to 2004 could leave with minimal costs and the option of a relatively easy return if things did not work out. However, membership, while

\footnotetext{
${ }^{5}$ In 2004 Poland joined the EU along with 9 other countries. Initially Poles had the right of free movement in the UK, Sweden and Ireland. There were caps to migration in other EU countries. In 2007 the caps were removed and Polish citizens gained the right to free movement across all EU countries (See BBC 2009. http://news.bbc.co.uk/2/hi/europe/ 3513889.stm\#uk).
} 
reducing transactional barriers, does not reduce social barriers (see Friberg, 2012a). Poles who chose to migrate outside the EU faced largely the same barriers and conditions as they would have prior to 2004 .

\section{Expectations}

Previous research has suggested that overall, Polish immigrants tend to fare well in many regimes (see Bevelander, 2000; Coyle, 2007; Drinkwater et al., 2010; Pendakur \& Pendakur, 2015). However little work has been done which directly compares and assesses outcomes for this important group in more than one country. We assess labour force outcomes for Polish migrants and their children in Canada and Sweden. These two countries are characterized by similarly high levels of permanent migration, relatively easy access to citizenship and a dominantly urban immigrant population. As well, both Canada and Sweden are next door to a much bigger economic engine-the United States for Canada and Germany for Sweden.

As noted above, we assess two dimensions of labour force involvement-employment probabilities and market income. We look at both the log and rank of market income because we argue that the rank provides a better measure when comparing across two countries with different earnings distributions. We hypothesize that Polish immigrants will have higher employment rates in Canada, where the minimum wage is relatively low and therefore entry into the labour market is easier as compared to Sweden (see Bevelander \& Pendakur, 2014).

Looking at the 2nd generation, previous research says that there should be few, if any differentials faced by the children of Polish immigrants-they are schooled and socialized in the host society and, for all intents and purposes are visibly identical to either Swedish-born Swedes or European-origin Canadians. In theory, second generation minorities (both men and women) should therefore approach the employment rate of the majority population.

The earnings distribution in Sweden is more compressed than in Canada. ${ }^{6}$ We account for this difference by assessing, not only the differentials in labour market income but also the rank of different groups in the income distribution. It is widely acknowledged that immigrants face earnings penalties in most host countries. It should not be surprising therefore to see Polish immigrants facing earnings penalties in both Canada and Sweden. However, unless there are substantial differences in selection of migrants, there is no reason to suspect that the earnings penalties faced by Poles should be different across countries. As was the case for employment, when looking at the native-born Polish population, we do not expect to see substantive earnings differentials in either labour market income or rank of labour market income as compared to the majority population.

As discussed earlier, the entry of Poland into the EU in 2004 had a major impact on Polish migration flows. From a policy perspective, entry rules remained the same in Canada, but eased in Europe. Polish migration to Canada slowed substantially and rose

\footnotetext{
${ }^{6}$ Sweden's minimum wage of roughly $125 \mathrm{Kr}$ per hour combined with a $50 \%$ payroll tax means the actual wage is almost $190 \mathrm{Kr}$ per hour. This, combined with a comparison of the Gini indexes in Canada and Sweden (.30 and .28) suggests that the earnings distribution is somewhat higher in Canada as compared to Sweden (OECD statistics https://data.oecd.org/ inequality/income-inequality.htm).
} 
in Sweden as EU barriers to migration were removed. In Sweden, because the easiest way to get permanency is to have a job, we expect to see high employment rates for Polish immigrants, but perhaps no real impact on earnings. In Canada, however, it is more ambiguous. Employment is not a precondition of entry for family class intake but for independent immigrants (which is roughly a third of the intake), having a job offer generally results in acceptance.

\section{Method}

We use data from the Canadian 2016 census provided by Statistics Canada and a Swedish 2015 Stativ dataset based on different registers held by Statistics Sweden to compare outcomes for different groups. These two data sources have the advantage of offering high quality and comparable data for Polish and other immigrant groups in their respective host countries. Both are defacto, mandatory. The Swedish register has information drawn from administrative sources on every legal resident in Sweden, while the Canadian census is a $25 \%$ sample of Canadian households drawn from a combination of a questionnaire and tax records. Timing for our dependent variables of interest is highly comparable. Employment status for Sweden is for November of 2015, while for Canada it is for May 2016. Income data for both Canada and Sweden are drawn from 2015 sources (tax data for Sweden and a combination of tax or self-reported income for Canada). As well, both Canada and Sweden use the same definition for most variables including country of birth, period of immigration, and place of birth of parents. The Canadian and Swedish variables for education are markedly different. The Canadian census asks about highest certificate and the Swedish register captures information on all types of schooling. Despite the differences, it is possible to create a comparable variable (as noted below).

We note that both datasets only collect information on permanent, legal residents. ${ }^{7}$ The Swedish register does not track temporary (short-term) workers or 'posted' worker. ${ }^{8}$

In both cases, we select people born in the host country (Canada or Sweden) and immigrants who arrived in two different periods. The first selection is for immigrants who arrive from 1980 to 2014. This selection corresponds to roughly an entire working life. The second selection is for immigrants who arrived from 2004 to 2014. This selection corresponds to the period in which Poland joined the EU and therefore the period in which Poles had mobility rights within the EU. We include only people age 25 to 64 thereby excluding the majority of students and other people who are not likely to be active in the labour force. ${ }^{9}$

\footnotetext{
7 Temporary foreign workers (TFWs) are people who are legally entitled to work in Canada for a specific period of time, generally less than two years. In Canada TFWs can get permanent residence but it is not guaranteed. It is possible to identify temporary foreign workers on the Canadian census, but because this is not possible in our Swedish dataset, these workers are dropped from the analysis.

${ }^{8}$ Posted workers are workers who may work in Sweden but are paid by a company based in the source country. In our case, these workers pay taxes in Poland and their pay does not show up in the Swedish system. These workers are not included in our sample because we only include people who are employed in Sweden.

9 For Canada, we also exclude households with more than 13 people. This serves to drop group homes and communes or group communities (i.e.: Mennonite communities).
} 
Analyses are done separately for men and women in recognition of the fact that they likely have different labour market histories and are affected by the presence of children in different ways.

We control for a number of basic personal characteristics including age and age squared as continuous variables, years in the host country and years squared (continuous variable), and marital status (single, married or living together in common-law, divorced or separated and widowed). Number of children is included as a 4-level dummy variable set (none, one child, two children or 3 and more children).

Education is included as a 4-level dummy variable set (less than high school, high school, post-secondary certificate and university degree). We also control for whether the person lives in one of the three largest cities in each country. For Sweden, we include dummies for the economic areas of Stockholm, Gothenburg, Malmö, versus other areas. For Canada, we include controls for the census metropolitan areas of Toronto, Montreal, Vancouver versus other areas.

Our specific interest is in outcomes for Polish immigrants and their children. Both the Swedish Register and the Canadian census allow us to identify individuals by place of birth as well as the place of birth of parents. We use these variables to identify the following groups of men and women:

- born in Poland,

- born outside Canada or Sweden, but not Poland.

- born in Canada or Sweden with two parents born in Poland

- born in Canada or Sweden with one parent born in Poland and the other born in Canada or Sweden. ${ }^{10}$

- Our comparison group is the population born in either Canada or Sweden with no parents born in Poland.

This categorization allows us to compare outcomes of Polish immigrants and their children to non-Polish immigrants as well as to the native-born population. We are particularly interested in outcomes for people who are ethnically Polish, but born in Canada or Sweden. The above categorization allows us to identify 2 groups, as defined by the number of Polish immigrant parents. This in turn allows us to assess the impact of Polish ancestry on outcomes for those born in Canada and Sweden. ${ }^{11}$

We assess the impact of these characteristics on three separate outcomes. First, we look at the probability of employment. For Canada our employment variable assesses whether or not the respondent is employed in the week of the census (May of 2015). For Sweden it measures whether or not a respondent is employed for the month of

\footnotetext{
${ }^{10}$ People born in Sweden with one Polish parent and the other parent born outside Canada or Sweden, but not Poland are dropped from the analysis. We note however, that this is a small group.

11 We note that the comparison group - Canadian or Swedish born permanent residents who do not have Polish parents - is a large group that includes people who are not in the majority (either Swedes born in Sweden or Canadians of British or French origin. However, the components of the subgroups are not comparable across countries, and we do not break them out in the analysis.
} 
November $2015 .^{12}$ In order to better explain the basic difference in employment rates between Canada and Sweden, we present marginal effects based on logistic regressions. This allows us to compare both within and across countries.

For earnings we look at two outcomes. The first is the log of annual income for work (either through employment or self-employment) in either 2015 Canadian dollars or 2015 hundreds of Swedish Kronor. We recognize that the income distributions are different in Canada and Sweden and that the purchasing power of Canadian dollars and Swedish Kronor is also different. It is therefore likely incorrect to directly compare either actual or log incomes. We thus also assess the percentile rank of job-related income in both countries. This allows us to define the degree to which membership in a group pushes incomes up or down in terms of percentage ranks as compared to the nativeborn (non-Polish) population. We are unable to test for the impact of working full time or part time, or for the number of weeks worked. These attributes are collected in Canada but not in Sweden. If Poles are more likely to work part time or if they only work part of the year we will be overestimating the earnings gap in Sweden, but perhaps not in Canada, where Polish immigrants are more likely to work full time.

The income ranks are calculated separately for Canada and Sweden for men and women. We calculate the rank by sorting pre-tax incomes of men and women in each country from lowest to highest to get each person's position in the income distribution and then dividing by the number of people to get a percentile rank. Our view is that these ranks are more comparable across countries as compared to the log of income. Using the rank allows us to compare a workers' placement in the country specific income distribution as compared to the actual income which can differ in terms of such things as buying power or income range. For both the log of market income and the income rank, we restrict our analysis to those earning more than $\$ 100 \mathrm{CAD}$ or 700 Swedish Kronor.

We run regressions (either logistic or OLS) on the probability of employment or income (either the log or rank) controlling for the variables listed above in order to understand the impact of being a Polish immigrant, or having a Polish background on these outcomes.

\section{Descriptive analysis}

Table 1 shows frequency counts for immigrants living in Canada and Sweden in 2015/16 who are born in Poland by period of immigration. In Canada, of the almost 150 thousand Polish immigrants who were resident in 2016, just over 40 percent arrived in the 1980s. About fourteen thousand Polish immigrants arrived over the past fifteen years. In Sweden, there has been a marked increase in intake from Poland since the mid 2000s, with almost forty percent of Polish immigrants arriving after 2005. These differences suggest that since Poland's entry into the EU, Polish immigration to Canada has slowed, while migration to Sweden has increased dramatically. Thus, we can conclude that EU entry offered Polish migrants an increase in their

\footnotetext{
12 The measures of employment are not exactly comparable. We use the standard European definition of employment being employed at a minimum of one base value during the month of November. The base employment value is defined as an annual income of at least 44,000 Kronor (equivalent to the social security payment). It is generally used to calculate the value of unemployment insurance. In Canada respondents are defined as employed if they worked for any duration during the census week (May 1 to May 7 2016). This means that the definition of employed is probably a bit stricter for Canada as compared to Sweden.
} 
Table 1 Population born in Poland, Canada (2016) and Sweden (2015)

\begin{tabular}{lll}
\hline & Canada & Sweden \\
\hline Total & 146,470 & 104,818 \\
Before 1981 & 33,300 & 10,686 \\
1981 to 1990 & 61,600 & 13,474 \\
1991 to 2000 & 37,475 & 7,161 \\
2001 to 2010 & 9,935 & 27,556 \\
2001 to 2005 & 4,970 & 6,840 \\
2006 to 2010 & 4,965 & 20,716 \\
2011 to $2015^{*}$ & 4,160 & 18,385 \\
\hline
\end{tabular}

Source: Statistics Canada 2016 Census table: 98-400-X2016185

For Sweden the data is drawn from the Swedish register

*For Canada the intake is 2011 to May 2016

Table 2 Population age 25-64 by sex, Native born and selected immigrant groups arriving between 1979 and 2015/16, Canada and Sweden

\begin{tabular}{lll}
\hline & Canada & Sweden \\
\hline Female & & \\
Total & $6,921,925$ & $2,342,739$ \\
$\quad$ Native born & $5,375,585$ & $1,895,320$ \\
$\quad$ Native-born (not Polish) & $5,357,420$ & $1,888,664$ \\
1 Polish immig. parent & 5,315 & 4,621 \\
2 Polish immig. parents & 12,850 & 2,035 \\
Immigrants & $1,546,340$ & 447,419 \\
Polish immigrants & 38,655 & 26,787 \\
Non-Polish immigrants & $1,507,685$ & 420,632 \\
Male & & \\
Total & $7,009,840$ & $2,407,648$ \\
Native born & $5,494,585$ & $1,977,477$ \\
Native-born (not Polish) & $5,475,850$ & $1,970,466$ \\
1 Polish immig. parent & 5,135 & 2,166 \\
2 Polish immig. parents & 13,600 & 4,845 \\
Immigrants & $1,515,255$ & 430,171 \\
Polish immigrants & 35,630 & 20,055 \\
Non-Polish immigrants & $1,479,625$ & 410,116 \\
\hline
\end{tabular}

Source: 2016 Census of Canada and 2015 Swedish register

choice of destination country allowing them to migrate closer destinations as compared to crossing the Atlantic. In this sense, Polish immigrants in Canada, could be considered a more established group, a possibility that is born out in Table 2.

Table 2 provides counts for our major groups of interest by sex for the population 25 to 64 . These data are drawn from the 2016 Canadian Census and 2015 register data for Sweden. Polish immigrants constitute the second largest EU group in Sweden (about 5 percent of the total immigrant population) and about 2 percent of Canada's immigrant population. As can be seen, there are 74 thousand Polish immigrants in Canada and almost 47 thousand Polish immigrants in Sweden who arrived from 1980 
Table 3 Mean employment, market income and income rank for selected groups by country and sex

\begin{tabular}{|c|c|c|c|c|}
\hline & \multicolumn{2}{|l|}{ Canada } & \multicolumn{2}{|l|}{ Sweden } \\
\hline & Female & Male & Female & Male \\
\hline \multicolumn{5}{|l|}{ Employment } \\
\hline Native-born not Polish & 0.74 & 0.79 & 0.85 & 0.86 \\
\hline 1 parent born in Poland & 0.78 & 0.73 & 0.80 & 0.80 \\
\hline 2 parents born in Poland & 0.65 & 0.78 & 0.75 & 0.74 \\
\hline Immigrant not polish & 0.67 & 0.82 & 0.59 & 0.65 \\
\hline Polish immigrant & 0.73 & 0.81 & 0.70 & 0.74 \\
\hline Labour market income & $C A D$ & & SEK & \\
\hline Native-born not Polish & 47,550 & 72,370 & 320,303 & 414,651 \\
\hline 1 parent born in Poland & 58,960 & 95,020 & 305,444 & 391,108 \\
\hline 2 parents born in Poland & 59,744 & 95,984 & 311,697 & 385,467 \\
\hline Immigrant not polish & 38,172 & 55,931 & 244,012 & 317,370 \\
\hline Polish immigrant & 44,989 & 61,279 & 255,682 & 318,777 \\
\hline \multicolumn{5}{|l|}{ Rank of income } \\
\hline Native-born not Polish & 0.52 & 0.52 & 0.52 & 0.52 \\
\hline 1 parent born in Poland & 0.56 & 0.56 & 0.49 & 0.49 \\
\hline 2 parents born in Poland & 0.57 & 0.55 & 0.50 & 0.47 \\
\hline Immigrant not polish & 0.44 & 0.44 & 0.38 & 0.37 \\
\hline Polish immigrant & 0.51 & 0.49 & 0.40 & 0.38 \\
\hline
\end{tabular}

to 2014. An additional 37 thousand people born in Canada and 14 thousand people born in Sweden have Polish parents. Thus, about half of Canada's Polish population is born in Canada, while this is true of about a quarter of Sweden's Polish population.

Table 3 provides information for our three dependent variables (employment probability, market income and income rank) for our groups of interest. Looking first at the employment level for Canada and Sweden we see that native-born women who do not have Polish parents are more likely to be employed in Sweden as compared to Canada (85\% and $74 \%$ respectively). In both Canada and Sweden, native-born women with two parents born in Poland are less likely to work than native-born women with one parent born in Poland.

Overall, the employment rate in Sweden is higher than the employment rate in Canada. In Sweden, about 85 percent of native-born non-Polish women and men are employed (74 percent and 79 percent in Canada respectively). Immigrant women in Sweden are far less likely to work as compared to native-born Swedes, however, immigrant women from Poland are more likely to work than immigrant women in general. Seventy percent of immigrant women from Poland are employed as compared to only 59 percent of immigrant women from other countries. In Canada, the employment rate for immigrants is higher than in Sweden. Indeed, immigrant men are at least as likely to work as native-born men.

As expected, for both Sweden and Canada, native-born workers have higher incomes than immigrants. Amongst women born in Sweden, incomes are fairly similar, regardless of whether or not people have parents born in Poland. However, amongst men, those with Polish parents do have lower average incomes. In Sweden, female immigrants from 
Poland have somewhat higher incomes than other immigrant women (256 thousand Kronor versus 244 thousand Kronor). However, amongst male immigrants, the incomes are statistically identical. In Canada, immigrant men from Poland have average earnings of 61 thousand dollars as compared to 72 thousand dollars for non-Polish native-born men. However native-born men with parents born in Poland have average labour market income that is substantially higher, at 95 thousand dollars.

The results seen for labour market income are reflected in the results for income rank but are more muted. This is because where the results for average income are heavily affected by the skewed distribution of income, ranks are not. Thus, in Canada, native born men and women with parents born in Poland are 3 to 5 percentage points higher in income rank as compared to other Canadian-born workers, while immigrants from Poland are 1 to 3 percentage points lower. In Sweden, native born men and women with parents born in Poland are 2 to 5 points lower in percent ranks as compared to other native-born workers, while immigrants are at least 12 points lower.

The descriptive statistics suggest that in Canada, Polish immigrants are less likely to be working as compared to the native-born population, but more likely to be employed than other immigrants. Native-born Swedes with parents from Poland are less likely to be employed, as compared to other native-born Swedes, while in Canada, the results are somewhat mixed. Immigrants in both Canada and Sweden earn, on average, a lot less than the native-born population, but those from Poland have higher average earnings than the rest of the immigrant population. The results for native-born workers in Canada as compared to Sweden are different, with native-born Poles in Sweden earnings somewhat less and those in Canada earning a lot more.

In terms of the Polish population, these results are encouraging for both Canada and Sweden, but do suggest that Poles in Canada do better. However, this could be a result of differences in the age or education profiles of the two populations. The following section uses standard regression techniques to control for these differences and explore the employment and income differentials in more depth.

\section{Regression results}

\section{Employment}

Table 4 shows marginal effects (estimated at the average of all coefficients) from four logistic regressions in which the dependent variable is the probability of being employed controlling for age, years since migration, schooling, marital status, number of children in the household and major city. ${ }^{13}$ There are separate regressions for each country and gender. The comparison group is native-born Canadians or Swedes who are not Polish in descent. The last column shows if the effects for Canada and Sweden are statistically different from each other. ${ }^{14}$

The results in Table 4 suggest that Canadian-born men and women with Polish parents have the same probability of being employed as other people born in Canada. However,

\footnotetext{
${ }^{13}$ Full results for all the regressions are available on request from the authors.

14 We determine if there is a significant difference between the two countries by calculating the $t$ value for independent samples:

$t=\left(\right.$ Coeffor Canada-Coef for Sweden)/sqrt(se for Canada + the $s^{2}$ for Sweden). A $t$ value of 2 or more is identified in the table.
} 
Table 4 Marginal effect (at the average of all coefficients) of being employed, Canada and Sweden, $2015 / 2016$

\begin{tabular}{|c|c|c|c|c|c|c|c|}
\hline & Canada & & & Sweden & & & \\
\hline & Coef & s.e & sig & coef & s.e & Sig & \\
\hline \multicolumn{8}{|l|}{ Female } \\
\hline Observations & $7,961,200$ & & & $2,342,739$ & & & \\
\hline R2 & 0.09 & & & 0.15 & & & \\
\hline \multicolumn{8}{|l|}{ Native-born not Polish (comparison) } \\
\hline Native-born with 1 parent born in Poland & 0.02 & 0.01 & & -0.04 & 0.00 & $* * *$ & $\dagger$ \\
\hline Native-born with 2 parents born in Poland & 0.00 & 0.01 & & -0.07 & 0.01 & $* * *$ & $\dagger$ \\
\hline Immigrant from Poland & -0.27 & 0.01 & $* * *$ & -0.38 & 0.00 & $* * *$ & $\dagger$ \\
\hline Other immigrant & -0.31 & 0.00 & $* * *$ & -0.48 & 0.00 & $* * *$ & $\dagger$ \\
\hline \multicolumn{8}{|l|}{ Male } \\
\hline Observations & $7,650,415$ & & & $2,407,648$ & & & \\
\hline R2 & 0.1 & & & 0.12 & & & \\
\hline \multicolumn{8}{|l|}{ Native-born not Polish (comparison) } \\
\hline Native-born with 1 parent born in Poland & 0.00 & 0.01 & & -0.05 & 0.00 & $* * *$ & $\dagger$ \\
\hline Native-born with 2 parents born in Poland & -0.01 & 0.01 & & -0.09 & 0.01 & $* * *$ & $\dagger$ \\
\hline Immigrant from Poland & -0.10 & 0.01 & $* * *$ & -0.25 & 0.00 & $* * *$ & $\dagger$ \\
\hline Other immigrant & -0.14 & 0.00 & $* * *$ & -0.40 & 0.00 & $* * *$ & $\dagger$ \\
\hline
\end{tabular}

The 2016 Census of Canada is a 25\% sample of Canadian households. As per Statistics Canada requirement we show the weighted number of observations

Significance: ${ }^{*} 0.1 ;{ }^{* *} 0.05 ;{ }^{* * *} 0.01$

Regressions control for age, age squared, years in the host country for immigrants, years in the host country squared, schooling, marital status, number of children and residence in the 3 largest cities

${ }^{\dagger}$ Indicates that the coefficients for Canada and Sweden are statistically different from each other at the 0.05 level

for immigrants, there are some substantial differences. Being a non-Polish immigrant women reduces the probability of employment by 31 percent. Immigrant women from Poland have somewhat better probabilities of being employed 27 percent.

In Sweden, all groups have a lower probability of being employed as compared to non-Polish native Swedes, ranging from -4 percent for native-born Poles with one Polish parent to -38 percent for Polish immigrants. As was the case for Canada, however, immigrant women from Poland have somewhat better probabilities of being employed as compared to non-Polish immigrants. In all cases, the results for Canada are statistically different from the results for Sweden.

In Canada, immigrant males are less likely to be employed as compared to Canadian-born males. Immigrants from Poland have somewhat better probabilities of being employed ( -10 percent as compared to -14 percent for non-Polish immigrants).

In Sweden, as was the case for women, all male immigrant groups face strong and statistically significant penalties of between -0.25 percent Polish immigrants and 40 percent for other immigrants. However, Swedish born Poles, while not meeting the probability of employment for other Swedes, face far smaller differentials $(-5$ percent for those with one Polish parent and $-9 \%$ for those with two Polish parents). Once again, the results for Canada are statistically different from the results for Sweden.

In interpreting the effects of employment and comparing across countries it is important to remember the labour force participation rates for women in Sweden are substantially higher than is the case for Canada. As such, at least part of the reason for the high 
differentials in Sweden as compared to Canada may be because the bar for comparison is so much higher. In Sweden the labour force participation rate for women is $85 \%$, while in Canada it is only $74 \%$. The large negative coefficients seen for immigrant women in Sweden as compared to Canada may be a product of the fact that such a high proportion of Swedish women are active in the labour force that the average negative effect for minority women in Sweden is greater than Canada.

Recalling results from Table 3, we see that 75 to $80 \%$ of Sweden-born Polish women are employed, and a similar 78 percent of Canadian-born women with one Polish parent are employed. The fact that so many non-Polish native-born Swedish women are employed means that the coefficient on employment for these Sweden-born Polish women will still be lower than is the case for Canada. For men, the participation rates are much closer. Indeed, for the population 15 plus they're almost identical (see OECD, 2007). It is therefore harder to argue, in the case of men, that the differences we are seeing are an artefact of the differences in participation rates across the two countries.

The reality is, however, that explaining away the cross-country differences as a product of differences in participation rates is easier to make in the case of immigrants as compared to Sweden-born Poles. It is possible that things like language, credentials and loss of social capital make it harder for immigrants to get jobs as compared to native-born Swedes. It is a more difficult argument to make in the case of Poles born in Sweden who share the same credentials and language ability as other Swedes particularly after controlling for basic characteristics such as age, education and marital status.

\section{Labour market income}

Table 5 shows results similar in form to those shown in Table 4, but in this case the dependent variable is the log of Labour Market income. Here the results can be interpreted (at least for coefficients less than 0.25 ) as percent differences from the comparison group. It should be noted however, that because the dependents are either Canadian dollars or Swedish kronor comparisons across countries are difficult to make.

Looking at the results for Canada, we see that native-born Poles, both men and women, have labour market incomes that are actually higher than is the case for other Canadian-born women. Canadian-born women with two Polish parents make an estimated 7\% more than other Canadian-born women. In the same way Canadian-born men with Polish parents earn 5\% and 7\% more than other Canadian-born men after controlling for personal characteristics.

Immigrants however, face earnings penalties in both Canada and Sweden, Immigrant women earn about $40 \%$ of what native-born women earn after controlling for personal characteristics. Immigrant men earn about half (coefficients for men in Canada of -0.74 and -0.64 for non-Polish immigrants and Polish immigrants respectively).

As was noted earlier, comparisons of income between Canada and Sweden are difficult both because the distribution of income is different and because the currency values are different. One way to control for these differences would be to calculate parity wages across the two countries however this would not necessarily take care of the differences in the distributions (see for example Bevelander \& Pendakur, 2014). We have chosen to look at the percentile rank of individual incomes within across the two countries instead. This involves sorting everybody in both countries from lowest wage to highest wage and 
Table 5 Difference in log of work related income, Canada and Sweden 2015

\begin{tabular}{|c|c|c|c|c|c|c|c|c|}
\hline & \multicolumn{4}{|l|}{ Canada } & \multicolumn{4}{|l|}{ Sweden } \\
\hline & coef & se & sig & $\%$ dif & coef & se & sig & $\%$ dif \\
\hline \multicolumn{9}{|l|}{ Females } \\
\hline Observations & $6,921,925$ & & & & $2,081,864$ & & & \\
\hline R2 & & 0.11 & & & & 0.18 & & \\
\hline \multicolumn{9}{|l|}{ Native-born not Polish (comparison) } \\
\hline Native-born with 1 parent born in Poland & 0.05 & 0.03 & * & 0.06 & -0.03 & 0.01 & $* * *$ & -0.03 \\
\hline Native-born with 2 parents born in Poland & 0.07 & 0.02 & $* * *$ & 0.08 & -0.04 & 0.02 & ** & -0.04 \\
\hline Immigrant from Poland & -0.87 & 0.01 & $* * *$ & -0.58 & -0.85 & 0.01 & $* * *$ & -0.57 \\
\hline Other Immigrant & -0.94 & 0.01 & $* * *$ & -0.61 & -0.94 & 0.00 & $* * *$ & -0.61 \\
\hline \multicolumn{9}{|l|}{ Male } \\
\hline Observations & $7,009,840$ & & & & $2,143,148$ & & & \\
\hline R2 & & 0.13 & & & & 0.14 & & \\
\hline \multicolumn{9}{|l|}{ Native-born not Polish (comparison) } \\
\hline Native-born with 1 parent born in Poland & 0.07 & 0.03 & ** & 0.07 & -0.07 & 0.01 & $* * *$ & -0.06 \\
\hline Native-born with 2 parents born in Poland & 0.05 & 0.02 & $* * *$ & 0.05 & -0.17 & 0.02 & $* * *$ & -0.15 \\
\hline Immigrant from Poland & -0.64 & 0.01 & $* * *$ & -0.47 & -0.59 & 0.01 & $* * *$ & -0.45 \\
\hline Other Immigrant & -0.74 & 0.01 & $* * *$ & -0.52 & -0.80 & 0.00 & $* * *$ & -0.55 \\
\hline
\end{tabular}

The 2016 Census of Canada is a $25 \%$ sample of Canadian households. As per Statistics Canada requirement we show the weighted number of observations

Significance: ${ }^{*} 0.1 ;{ }^{* *} 0.05 ;{ }^{* * *} 0.01$

Regressions control for age, age squared, years in the host country for immigrants, years in the host country squared, schooling, marital status, number of children and residence in the 3 largest cities

then calculating the percent ranking of every individual in each country. Comparing the ranks allows us to ask where in the distribution different groups fall. Another interpretation is that the coefficient on income rank provides the controlled impact that membership in the group offers in terms of moving up or down the percentile ranks of each country's distribution. It is our view that these coefficients are more comparable across countries.

Table 6 shows these results. Interestingly, by and large, immigrants in both Canada and Sweden face about the same percent income rank penalty. In both countries, being a female immigrant is correlated with a $25-27$ percent drop in income rank. Immigrant males do a little bit better and have income rank drop of about 21-26 percentage points.

For the native-born population, we find a relatively small difference between the countries. Being of Polish background born in Canada is associated with a small bonus of about two percentage points for both men and women. In Sweden, native-born Polish women have about the same income rank while men see a small disadvantage of between 2 and 4 percentage points compared to other native-born Swedes. The country level results are significantly different from each other suggesting that native-born Poles in Canada fare better in terms of income rank than those in Sweden.

\section{Results for recent immigrants}

Poland joined the European Union in 2004. In our data, which captures Swedish data for 2015, Polish citizens could move freely within the EU for 11 years. Looking at Table 1, we see that EU entry appears to have changed the flow of Poles away from Canada and 
Table 6 Difference in rank of income, Canada and Sweden, 2015

\begin{tabular}{|c|c|c|c|c|c|c|c|}
\hline & Canada & & & Sweden & & & \\
\hline & coef & se & sig & coef & se & sig & \\
\hline \multicolumn{8}{|l|}{ Females } \\
\hline \multirow[t]{2}{*}{ Observations } & $6,921,925$ & & & $2,081,864$ & & & \\
\hline & $\mathrm{R} 2$ & & 0.18 & & & 0.25 & \\
\hline \multicolumn{8}{|l|}{ Native-born not Polish (comparison)] } \\
\hline Native-born with 1 parent born in Poland & 0.02 & 0.01 & $* * *$ & -0.01 & 0.00 & $* * *$ & $\dagger$ \\
\hline Native-born with 2 parents born in Poland & 0.02 & 0.00 & $* * *$ & 0.00 & 0.01 & & $\dagger$ \\
\hline Immigrant from Poland & -0.26 & 0.00 & $* * *$ & -0.26 & 0.00 & $* * *$ & \\
\hline Other Immigrant & -0.27 & 0.00 & $* * *$ & -0.25 & 0.00 & $* * *$ & $\dagger$ \\
\hline \multicolumn{8}{|l|}{ Male } \\
\hline Observations & $7,009,840$ & & & $2,143,148$ & & & \\
\hline R2 & & 0.19 & & & 0.22 & & \\
\hline \multicolumn{8}{|l|}{ Native-born not Polish (comparison)] } \\
\hline Native-born with 1 parent born in Poland & 0.02 & 0.01 & $* * *$ & -0.02 & 0.00 & $* * *$ & $\dagger$ \\
\hline Native-born with 2 parents born in Poland & 0.02 & 0.00 & $* * *$ & -0.04 & 0.01 & $* * *$ & $\dagger$ \\
\hline Immigrant from Poland & -0.21 & 0.00 & $* * *$ & -0.23 & 0.00 & $* * *$ & + \\
\hline Other Immigrant & -0.24 & 0.00 & $* * *$ & -0.26 & 0.00 & $* * *$ & $\dagger$ \\
\hline
\end{tabular}

The 2016 Census of Canada is a 25\% sample of Canadian households. As per Statistics Canada requirement we show the weighted number of observations

Significance: ${ }^{*} 0.1 ;{ }^{* *} 0.05 ;{ }^{* * *} 0.01$

Regressions control for age, age squared, years in the host country for immigrants, years in the host country squared, schooling, marital status, number of children and residence in the 3 largest cities

${ }^{\dagger}$ Indicates that the coefficients for Canada and Sweden are statistically different from each other

toward Sweden (which is both closer and offers easier entry). We therefore do a separate set of analyses for immigrants who arrived in Canada or Sweden during the 2004 to 2014 period. In these regressions we do not include native-born Poles because the population is too young to be active in the labour force. These regressions allow us to explore the impact of EU membership on outcomes for Polish immigrants.

Table 7 shows results from 12 regressions in which the dependent variable is either the probability of employment (based on marginal effects predicted at the average of all coefficients), the log of labour market income or the percentile rank of labour market income. We provide results for males and females and for Canada and Sweden. As with previous analyses, the last column on employment and income rank indicates whether or not the coefficients for Canada and Sweden are statistically different from each other.

Looking at employment for women we see a similar pattern as we saw for all immigrants in Table 4. In Canada as compared to the Canadian-born population, the probability of employment decreases by 36 percent for non-Polish immigrants and 32 percent for Polish immigrants. In Sweden it is 61 percent lower for non-Polish immigrants and 45 percent lower for Polish immigrants. Looking at the results for males, we see that in Canada recent immigrants from Poland are 11 percent less likely to be employed as compared to Canadian-born males, while in Sweden, the figure is -29 percent. In all cases, the results for Canada and Sweden are statistically different from each other.

Turning to the results for log of income we see that being a Polish immigrant woman in Canada is correlated with a 63 percent reduction in income (coefficient of -0.99 ) while 
Table 7 Employment and income differentials for selected groups, native born and immigrants arriving from 2004 to 2014, Canada and Sweden, 2015/2016

\begin{tabular}{|c|c|c|c|c|c|c|c|}
\hline & Canada & & & Sweden & & & \\
\hline & coef & se & $\overline{s i g}$ & coef & se & sig & \\
\hline Female & & & & & & & \\
\hline Employment (marginal ef & & & & & & & \\
\hline Observations & $6,848,585$ & & & $2,110,196$ & & & \\
\hline $\mathrm{R} 2$ & 0.10 & & & 0.15 & & & \\
\hline Native-born, non Pole (c & & & & & & & \\
\hline Immigrant from Poland & -0.32 & 0.02 & $* * *$ & -0.45 & 0.01 & $* * *$ & $\dagger$ \\
\hline Other Immigrant & -0.36 & 0.01 & $* * *$ & -0.61 & 0.00 & $* * *$ & $\dagger$ \\
\hline Log of Job related income & & & & & & & \\
\hline Observations & $5,954,550$ & & & $1,891,668$ & & & na \\
\hline $\mathrm{R} 2$ & 0.12 & & & 0.19 & & & \\
\hline Native-born, non Pole (c & & & & & & & \\
\hline Immigrant from Poland & -0.99 & 0.04 & $* * *$ & -1.06 & 0.01 & $* * *$ & \\
\hline Other Immigrant & -1.05 & 0.01 & $* * *$ & -1.24 & 0.00 & $* * *$ & \\
\hline Percent rank of income & & & & & & & \\
\hline Observations & $5,954,550$ & & & $1,891,668$ & & & \\
\hline R2 & 0.18 & & & 0.26 & & & \\
\hline Native-born, non Pole (c & & & & & & & \\
\hline Immigrant from Poland & -0.28 & 0.01 & $* * *$ & -0.29 & 0.00 & $* * *$ & \\
\hline Other Immigrant & -0.28 & 0.00 & $* * *$ & -0.29 & 0.00 & $* * *$ & \\
\hline Male & & & & & & & \\
\hline Employment (marginal ef & & & & & & & \\
\hline Observations & $6,642,675$ & & & $2,191,639$ & & & \\
\hline R2 & 0.11 & & & 0.12 & & & \\
\hline Native-born, non Pole (c & & & & & & & \\
\hline Immigrant from Poland & -0.11 & 0.03 & $* * *$ & -0.29 & 0.01 & $* * *$ & $\dagger$ \\
\hline Other Immigrant & -0.21 & 0.01 & $* * *$ & -0.48 & 0.00 & $* * *$ & $t$ \\
\hline Log of Job related income & & & & & & & \\
\hline Observations & $6,086,480$ & & & $1,966,344$ & & & na \\
\hline R2 & 0.14 & & & 0.14 & & & \\
\hline Native-born, non Pole (c & & & & & & & \\
\hline Immigrant from Poland & -0.63 & 0.04 & $* * *$ & -0.79 & 0.01 & $* * *$ & \\
\hline Other Immigrant & -0.86 & 0.01 & $* * *$ & -1.04 & 0.00 & $* * *$ & \\
\hline Percent rank of income & & & & & & & \\
\hline Observations & $6,086,480$ & & & $1,966,344$ & & & \\
\hline $\mathrm{R} 2$ & 0.19 & & & 0.23 & & & \\
\hline Native-born, non Pole (c & & & & & & & \\
\hline Immigrant from Poland & -0.19 & 0.01 & $* * *$ & -0.26 & 0.00 & $* * *$ & + \\
\hline Other Immigrant & -0.26 & 0.00 & $* * *$ & -0.29 & 0.00 & $* * *$ & t \\
\hline
\end{tabular}

The 2016 Census of Canada is a 25\% sample of Canadian households. As per Statistics Canada requirement we show the weighted number of observations

Significance: ${ }^{*} 0.1 ;{ }^{* *} 0.05 ;{ }^{* * *} 0.01$

Controls: Regressions control for age, age squared, years in the host country for immigrants, years in the host country squared, schooling, marital status, number of children and residence in the 3 largest cities

${ }^{\dagger}$ Indicates that the coefficients for Canada and Sweden are statistically different from each other 
being a Polish immigrant in Sweden is correlated with a similar reduction in income of about 65 percentage points (coefficient of -1.06 ). These are almost identical suggesting that Polish women do equally well in both host countries. Using ranked incomes allows us to compare across countries. Here we see that being a Polish immigrant woman in Canada or Sweden reduces the rank by 28 to 29 percentage points. Thus, for women, both the income differential and the impact of being a Polish immigrant on the income rank are similar across countries.

The results for men are more pronounced. For men we see larger differences across countries for employment. In Canada being an immigrant from outside Poland reduces the probability of employment by $1.12 \mathrm{log}$ units while being a Polish immigrant reduces it by $0.65 \mathrm{log}$ units. In Sweden, being an immigrant from outside Poland reduces the probability of employment by $2.51 \log$ units and $1.73 \log$ units for Polish immigrants. For Poles, this is equivalent to reducing the odds of employment by over $80 \%$. Overall, for both countries Polish immigrants fare better than non-Polish immigrants in the labour force however the difference between Canada and Sweden is large in magnitude and the difference is statistically significant suggesting that immigrants have an easier time getting employment in Canada. Thinking back to our original suppositions, this suggests that Canada's selection system and the barriers to entry into Canada result in Polish immigrants who are more likely to be employed as compared to Sweden where barriers to entry and distance are low.

Looking at labour market incomes we see a similar pattern. In Canada immigrants have much lower incomes than Canadian-born workers however Polish immigrants face a smaller earnings penalty as compared to other immigrants. Polish immigrants in Canada have incomes that are about 47 percent lower than Canadian-born workers, while other immigrants earn about 58 percent less after controlling for personal characteristics (coefficients of -0.63 and -0.86 respectively). The same general pattern is true in Sweden but the penalties are somewhat higher. Polish immigrant males in Sweden earn about 55 percent less than Swedes while other immigrants earn about 65 percent less (coefficients of -0.79 and -1.04 respectively).

Finally looking at the rank of income we see that in Canada, being an immigrant is correlated with a roughly 26 percentage point drop in the percent rank of income. Polish immigrants fare better, facing a 19 percentage point reduction in income rank. In Sweden however being a Polish immigrant is correlated with a reduction of about 26 percentage points in the rank of income. Other immigrants face a larger income rank gap. In all cases the coefficients are statistically different between countries.

\section{Discussion}

Poland has been an important source of immigration in the past and with the fall of the Soviet Union this migration has strengthened considerably. As noted, with Poland's subsequent membership in the European Union Polish migration became politicized as a source of skilled migration that could substitute for local labour or complement labour demands (see for example Ciupijus, 2011; Drinkwater et al., 2010). Indeed, Poland is now the one of the largest sources of immigrants in Europe with the Polish Ministry of 
Foreign Affairs estimating that in 2019, 15-20 million Poles lived outside Poland (Ministry of Foreign Affairs, Republic of Poland, 2019). ${ }^{15}$ Thus the Polish diaspora is large, dispersed and particularly since 2004, politicized as both a source of necessary labour and a threat to local labour.

A comparison of Polish migration to Canada and Sweden allows us to assess differences over time and place within the context of the changing migration policy brought on by EU membership. Polish migration to Canada is longstanding but since Poland's entry into the EU, is declining. Polish migration to Sweden is also longstanding, but prior to 2004, of a much lower magnitude while after 2004, intake has grown almost exponentially.

Comparing key labour market outcomes for Polish migrants and their children these two countries allows us to assess how this important group fares across policy and labour market regimes. Canada selects a portion of its intake based on labour market requirements and migration is expected to be permanent in nature. Further, because the diaspora is well established, entry for new migrants may be eased. In Sweden, EU membership has afforded Poles mobility rights to work and settle since 2004 (Wadensjö, 2007). However, as compared to migration to Canada, EU migration may be considered more temporary in nature, particularly in the early years, because travel distances are short. Thus the risk of moving for the potential migrant within the EU is simply lower than the relative risk of moving to Canada.

In this paper we have looked at three economic outcomes for Polish immigrants and their children in Canada and Sweden: the probability of employment, the log of market income and the percentile rank of market income. Overall, we find that, particularly amongst men, Polish immigrants face smaller differentials in employment in Canada as compared to Sweden. However, when looking at income rank, the outcomes are basically the same in Canada and Sweden. The results for Polish immigrants on employment echo those found in Pendakur \& Pendakur, 2015 for Canada, and Bevelander, 2000 and Rosholm et al (2006) for Sweden (see also Levrau et al. 2013, Kogan, 2010 and Drinkwater et al., 2010). There is no similar research looking at the second-generation population in Sweden, however the findings for Canada are comparable to Pendakur \& Pendakur, 2015.

Polish immigrants fare about the same in both countries, facing a - $26 \%$ percentile gap for women. Polish immigrant men face a percentile rank penalty of $-21 \%$ in Canada and $-23 \%$ in Sweden. In terms of earnings, native-born Poles see a small bonus in the percentile rank in Canada and a small penalty in Sweden as compared to other native-born groups. Looking at the post-2004 cohort of Polish immigrants we see that Polish women fare about the same in Canada and Sweden in both employment and earnings. However, Polish immigrant men have higher employment and income prospects in Canada as compared to Sweden.

While there is previous research on labour force outcomes for Polish immigrants, there is far less research on native-born Poles in Canada, and none for Sweden. Our expectation was that Poles born in Canada or Sweden would not face substantive employment

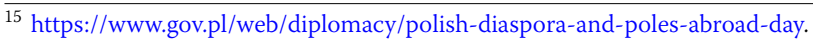


or earnings differentials because they are schooled and socialized in the country. These expectations were largely met for Canada, and Sweden where native-born Poles have similar outcomes. However, we note that this is only true for employment if you compare the actual employment rate across countries. Comparing within countries, we see that native-born Poles have lower employment probabilities than other native-born Swedes, but this is largely because Native-born Swedes have very high employment rates.

At least part of the country level differences may be a product of differences in migration history (Heydenkorn, 2009). Canada has a much longer history of migration and European communities in particular are well established and institutionally, perhaps more complete than is the case for Sweden (see Breton, 1964). In addition, Canada's labour market may offer easier entrance than is the case for Sweden because the minimum wage and job security is higher in Sweden than Canada which can tighten the Swedish labour market.

There are possible selection issues. Immigrating to Canada from Poland is perhaps more of a long-term commitment than crossing the Baltic by ferry. Immigrants from Poland to Canada may be, both more likely to be vetted via the point system and more likely to stay in Canada once there. Concomitantly, the easiest way to get permanent residence for post 2004 Poles in Sweden is to get a job after entry, which suggests that employment probabilities in Sweden should perhaps be higher than is the case for Canada. Membership in the EU along with the rights to mobility that come with membership could mean that post-2004 Poles have a lower commitment to permanency in Sweden than was previously the case. However, a comparison of the results for all immigrants to post-2004 immigrants suggests that overall, outcomes for recent Polish immigrants are lower than is the case for older cohorts. But, any differences could be easily attributed to the amount of time spent in the country.

As is to be expected being born in Canada or Sweden has a massive impact on employment and earnings (see Forrest \& Kusek, 2016). Second generation Poles in Canada have almost identical employment and earnings profiles to the rest of the Canadian-born population while second generation Poles in Sweden see a huge catch-up compared to their parents. Being a second-generation Pole in Canada or Sweden is correlated with a roughly 20-25-point gain in income rank as compared to their parents. Thus, while their parents may be the underpaid "plumbers" and "nurses", the children appear to have almost caught up in Sweden and have overtaken their peers in Canada.

\section{Acknowledgements}

Not applicable.

Authors' contributions

Both authors read and approved the final manuscript.

Funding

Open access funding provided by Malmö University.

Availability of data and materials

Not applicable.

\section{Declarations}

Competing interests

The authors declare that they have no competing interests. 


\section{Author details}

${ }^{1}$ Graduate School of Public and International Affairs, University of Ottawa, Ottawa, ON, Canada. ${ }^{2}$ Malmö Institute for Studies of Migration, Diversity, and Welfare, Malmö University, Malmö, Sweden.

Received: 12 August 2020 Accepted: 10 October 2021

Published online: 09 December 2021

\section{References}

Antecol, H., et al. (2003). Immigration Policy and the Skills of Immigrants to Australia, Canada, and the United States. Journal of Human Resources, 38(1), 192-218.

BBC. (2006). EU thumbs-up for 'Polish plumber'. http://news.bbc.co.uk/2/hi/uk_news/7735603.stm.

BBC. (2009). EU free movement of labour map http://news.bbc.co.uk/2/hi/europe/3513889.stm\#uk.

Becker, G. (1992). Human capital and the economy. Proceedings of the American Philosophical Society, 136(1), 85-92.

Bevelander, P. (2000). Immigrant Employment Integration and Structural Change in Sweden, 1970-1995. Lund: Lund Studies in Economic History.

Bevelander, P. (1999). The employment integration of immigrants in Sweden. Journal of Ethnic and Migration Studies, 25(3), 445-468. https://doi.org/10.1080/1369183X.1999.9976695

Bevelander, P., \& Pendakur, R. (2014). The labour market integration of refugees and family reunion immigrants: A comparison of outcomes in Canada and Sweden. Journal of Ethnic and Migration Studies, 40(5), 689-709.

Borjas, G. (1994). The economics of immigration. Journal of Economic Literature, 32(4), 1667-1717.

Breton, R. (1964). Institutional completeness of ethnic communities and the personal relations of immigrants. American Journal of Sociology, 70(2), 193-205.

Burrell, K. (2010). Staying, returning, working and living: Key themes in current academic research undertaken in the UK on migration movements from Eastern Europe. Social Identities, 16(3), 297-308.

Chiswick, B. (1978). The effect of Americanization on the earnings of foreign-born men. The Journal of Political Economy, 85(5), 897-921.

Chiswick, B., Lee, Y. L., \& Miller, P. (2005). A longitudinal analysis of immigrant occupational mobility: A test of the immigrant assimilation hypothesis. International Migration Review, 39(2), 332-353.

Cieslik, A. (2011). Where do you Prefer to Work? How the Work Environment Influences Retrun Migration Decisions from The United Kingdom to Poland. Journal of Ethnic and Migration Studies, 37(9), 1367-1383.

Ciupijus, Z. (2011). Mobile central Eastern Europeans in Britain: Successful European Union citizens and disadvantaged labour migrants? Work, Employment and Society, 25(3), 540-550. https://doi.org/10.1177/0950017011407962

Coyle, A. (2007). Resistance, regulation and rights: The Changing Status of Polish Women's Migration and Work in the 'New' Europe. European Journal of Women's Studies, 14(1), 37-50. https://doi.org/10.1177/1350506807072316

Dahlstedt, I. (2015). Over-education amongst the children of immigrants in Sweden. Nordic Journal of Migration Research, 5(1), 36-46. https://doi.org/10.1515/njmr-2015-0003

Datta, A., \& Brickell, K. (2009). "We have a little bit more finesse, as a nation": Constructing the Polish worker in London's building sites. Antipode, 41(3), 439-464.

Drozdzewski, D. (2011). Waves of Migration Exclusion and Inclusion: the experiences of Polish Australians. In M. Lobo \& F. Mansouri (Eds.), Migration, citizenship and intercultural relations: Looking through the lens of social inclusion (pp. 59-74). London: Ashgate.

Drinkwater, S., et al. (2010). "What's behind the figures? An investigation into recent Polish migration to the U.K. In R. Black, et al. (Eds.), A continent moving West? EU Enlargement and Labour Migration from Central and Eastern Europe (pp. 73-88). Amsterdam: Amsterdam University Press.

Duvander, A. (2001). Do country specific skills lead to improved labour market positions? An analysis of employment and labour market returns to education among immigrants in Sweden. Work and Occupations., 28(2), 210-233.

Eurostat. (2020). Migration and Migrant Population Statistics. https://ec.europa.eu/eurostat/statistics-explained/index.php? title=Migration_and_migrant_population_statistics\#Migrant_population:_22.3_million_non-EU_citizens_living_ in_the_EU_on_1_January_2018.

Forrest, J., \& Kusek, W. (2016). Human capital and the structural integration of Polish Immigrants in Australia in the First, Second and Third Generations. Australian Geographer, 47(2), 233-248. https://doi.org/10.1080/00049182.2016.11481 03

Friberg, J. (2012a). Culture at work: Polish migrants in the ethnic division of labour on Norwegian construction sites. Ethnic and Racial Studies, 35(11), 1914-1933.

Friberg, J. (2012b). The stages of migration. From going abroad to settling down: Post-accession polish migrant workers in Norway. Journal of Ethnic and Migration Studies, 38(10), 1589-1605. https://doi.org/10.1080/1369183X.2012. 711055

Friberg, J., Arnholtz, J., Eldring, L., Hansen, N., \& Thorarins, F. (2014). Nordic labour market institutions and new migrant workers: Polish Migrants in Oslo, Copenhagen and Reykjavik. European Journal of Industrial Relations, 20(1), $37-53$. https://doi.org/10.1177/0959680113516847

Garapich, M. (2008). The migration industry and civil society: Polish immigrants in the United Kingdom Before and After EU Enlargement. Journal of Ethnic and Migration Studies, 34(5), 735-752. https://doi.org/10.1080/136918308021059 70

Gorodzeisky, A., \& Semyonov, M. (2017). Labor force participation, unemployment and occupational attainment among immigrants in West European countries. PLOS ONE, 12(5), e0176856. https://doi.org/10.1371/journal.pone.0176856

Heydenkorn, B. (2009). Polish Canadians. The Canadian Encyclopaedia. https://www.thecanadianencyclopedia.ca/en/ article/poles. 
Kaczmarczyk, P., \& Tyrowicz, J. (2015). Winners and Losers among skilled migrants: The case of post-accession Polish Migrants to the UK. IZA Discussion Papers, No. 9057, Institute for the Study of Labor (IZA).

Knight, J., Lever, J., \& Thompson, A. (2014). The labour market mobility of polish migrants: A comparative study of three regions in South Wales, UK. Central and Eastern European Migration Review, 3(2), 61-78.

Kogan, I. (2010). New immigrants—Old disadvantage patterns? Labour market integration of recent immigrants into Germany. International Migration. https://doi.org/10.1111/j.1468-2435.2010.00609.x

Lehmer, F., \& Ludsteck, J. (2011). The immigrant wage gap in Germany: Are East Europeans Worse Off? International Migration Review, 45(4), 872-906.

Leonard, D. (2014). Exploding the myth of the Polish Plumber. Politico.

Levrau, F., Piqueray, E., Goddeeris, I., \& Timmerman, C. (2013). Polish immigration in Belgium since 2004: New dynamics of migration and integration? Ethnicities, 14, 303-323.

Markowski, S., \& Kwapisz-Williams, K. (2013). Australian Polonia: A Diaspora on the Wane? Central and Eastern European Migration Review, 2(1), 13-36.

Miera, F. (2008). Transnational strategies of Polish Migrant Entrepreneurs in trade and small business in Berlin. Journal of Ethnic and Migration Studies, 34(5), 753-770. https://doi.org/10.1080/13691830802106010

Ministry of Foreign Affairs, Republic of Poland. (2019). Polish Diaspora. Poland Ministry of Foreign Affairs. https://www. gov.pl/web/diplomacy/polish-diaspora-and-poles-abroad-day.

Nowicka, M. (2013). Positioning strategies of Polish entrepreneurs in Germany: Transnationalizing Bourdieu's Notion of Capital. International Sociology, 28(1), 29-47. https://doi.org/10.1177/0268580912468919

Odé, A. (1996). Migrant workers in the Dutch Labour Market. Amsterdam: Tindberg Institute. Ph.D. dissertation.

OECD. (2007). International Migration Outlook 2007. OECD Publishing. https://doi.org/10.1787/migr_outlook-2007-en Pendakur, K. \& Pendakur, R. (2015). The colour of money redux: earnings differentials amongst ethnic groups 1991-2006.

In C. Teixeira \& W. Li (Eds.), The housing and economic experiences of immigrants in North American Cities. Toronto: University of Toronto Press.

Pendakur, K., \& Pendakur, R. (1998). The colour of money: Wage differentials across ethnic groups. Canadian Journal of Economics, 3, 518-548.

Rosholm, M., et al. (2006). The times they are a changing: Declining immigrant employment opportunities in Scandinavia. International Migration Review, 40(2), 318-347.

Wadensjö, E. (2007). Migration to Sweden from the New EU Member States. IZA discussion paper series, No: 3190

Wagner, I. (2019). Why freedom of movement is causing divisions-across Europe? The Guardian.

\section{Publisher's Note}

Springer Nature remains neutral with regard to jurisdictional claims in published maps and institutional affiliations.

\section{Submit your manuscript to a SpringerOpen ${ }^{\circ}$ journal and benefit from:}

- Convenient online submission

- Rigorous peer review

- Open access: articles freely available online

- High visibility within the field

- Retaining the copyright to your article

Submit your next manuscript at $\mathbf{s p r i n g e r o p e n . c o m ~}$ 